\title{
Opinions of Educational Administrators on Glass Ceiling Syndrome Preventing Women from Becoming Senior Managers
}

\author{
Burcu Akkaya \\ Correspondence: Burcu Akkaya, Dr. Literature Teacher. Ministry of National Education, Turkey. \\ E-mail: akkaya.eyt@ gmail.com ORCID: https://orcid.org/0000-0002- 4571-9065
}

Received: December 16, 2019

Accepted: February 18, $2020 \quad$ Online Published: February 20, 2020

doi:10.11114/jets.v8i3.4658

URL: https://doi.org/10.11114/jets.v8i3.4658

\begin{abstract}
The purpose of this study is to reveal the opinions of educational administrators about the factors that arise from the glass ceiling syndrome which prevents women from becoming senior managers in educational organizations. In addition, in this study, suggestions have been developed for women to overcome the obstacles they face in reaching senior management positions. Qualitative method was used in this research. The research was conducted as a descriptive study in the survey model. The participants of the study consisted of educational administrators working in Niğde province. Semi-structured interview technique was used to examine and reveal the views of the participants in depth. Content analysis method was used in the analysis of data. According to the results, all participants think that women face glass ceiling barriers in the promotion of senior managerial positions. Obstacles to the glass ceiling are mostly due to individual factors. Individual factors were followed by organizational and social factors, respectively. Among the individual factors, the most important obstacles are women's negative view of management and their family responsibilities. Women do not aspire to management tasks because they require more workload and responsibility. In addition, male-dominated organizational policies and the sexist approach, which sees management as man's job are barriers for women. It has been suggested that women should be more willing and challenging to overcome the glass ceiling barriers. In addition, suggestions were made for senior management positions such as allocating quotas and providing flexible working hours for women.
\end{abstract}

Keywords: women administrators, senior managers, social gender, gender discrimination

\section{Introduction}

Women began to work in paid jobs with the industrial revolution, and a working woman role was added to the women's roles of mother, spouse, and housewife. However, employment rates, working conditions and career opportunities of working women have always been more disadvantaged than men. Compared to men, women's employment rates and wages are lower and career opportunities have always been limited. Women participate in the labor market at all levels, raise their level of education, and prepare for senior positions that traditionally belong to men (Palmer and Hyman, 1993). Despite the slow but steady increase in the share of women in the working life, progress in organizational hierarchies continues to be hampered. In employment, there is a tendency for women to be placed in jobs that are low in wages, and therefore women find themselves in non-strategic jobs rather than higher positions and managerial jobs (Wirth, 2004).

The implicit barriers that do not allow women to rise to top managerial positions in organizations are called 'glass ceiling'. The concept of 'glass ceiling' was first used in the 'Corporate Woman' report of The Wall Street Journal in the USA (Hymowitz \& Schellhardt, 1986). The U.S. Federal Glass Ceiling Commission (1995) defined the concept as "the unseen, yet unbreachable barrier that keeps minorities and women from rising to the upper rungs of the corporate ladder, regardless of their qualifications or achievements".

Glass ceiling barriers are often hidden behind legitimate and natural-looking practices as an extension of gender discrimination (Akdol, 2009). Glass ceiling barriers that inhibit the professional career of women are behavioral barriers consisting of largely unconscious stereotypes and prejudices, rather than physical (Schwartz, 2006). These transparent barriers function to exclude women from senior managerial positions (Hu and Yun, 2008). Working women are paid less than men who has the same profession, experience and seniority. Many international conventions, which are parties to the prevention of discrimination against women, have often not been implemented (Narin, Marsap and Gurol, 2006). The male-dominated culture, which excludes women from decision-making processes, has resulted in men being more 
dominant in working life than women today in many countries (Erdem, Tuzlukaya and Selcuk, 2013).

Although recent global statistics show that women continue to increase their share of managerial positions, progress is slow, unstable and sometimes discouraging. Female managers are rarely seen in male-dominated professions, while male managers are more common in female-dominated professions (Wirth, 2004). Despite the increase of participation in maledominated professions, women are still rarely seen in senior managerial positions, even in rich industrialized societies (Acker, 2009). Only $6 \%$ of the highest paid chairman, general manager and chief operating officer (CEO) positions of Fortune 500 companies are women. $2 \%$ of CEOs and $15 \%$ of executives on the boards of directors are women. $11 \%$ of the top executives of the 50 largest publicly traded companies in the EU countries, and $4 \%$ of the chairmen and CEOs are women. In the Global 500, determined by Fortune magazine, seven female CEOs are employed in seven companies, representing only $1 \%$ (Eagly and Carli, 2007).

Turkey's place in the international ranking is very poor in terms of gender-based discrimination and inequality. In 2013, according to the Gender Inequality Index (GII) in Human Development Report [HDR] published by United Nations (UN), Turkey, with a GII value of 0.360 , was ranked 69th among 149 countries. The rate of women representation in the parliament in Turkey $14.2 \%$. The proportion of those who have completed at least secondary education $39 \%$ among adult women, while men were identified as $60 \%$. While the participation rate of women in the labor market is $29.4 \%$, the participation rate of men is $70.8 \%$. In the report, Turkey's expression was seen in OECD countries was the lowest level of gender equality (UNDP in Turkey, 2014).

In the report prepared by KA-DER (2015), the representation ratios of women in authority and decision-making positions are summarized as follows: Only 1 (4\%) of 25 undersecretaries working in 25 ministries, 2 (2.4\%) of 81 governors, 1 $(14.2 \%)$ of 7 heads of high judicial organs, 1 (14\%) of 14 employer and professional organization heads is female. 14 of 174 universities (8.05\%) have female rectors. In the academic staff, 5,337 (30.20\%) of 17,670 professors, 4,017 (34.06\%) of 11,791 associate professors, 9,786 (37.6\%) of 26,017 assistant professors, 21,565 (51.72\%) of 41,691 research assistants are women.

Glass ceiling barriers faced by women in organizations have been discussed in different categories in the literature. According to the most common of these classifications, three main factors that create glass ceiling barriers are individual, organizational and social factors (Mizrahi and Arac1, 2010). According to this classification, women's multiple roles, personal preferences and perceptions constitute barriers arising from individual factors. Organizational culture and policies, lack of mentors and inability to participate in communication networks are also examined as barriers arising from organizational factors. Finally, it is seen that the barriers arising from social factors are consist of stereotypes and profession discrimination (Karaca, 2007).

Although men are increasingly involved in household chores and childcare, the burden is still on women's shoulders. Many women are forced to slow their career progress due to family responsibilities. In the 2005 family survey in the USA, it was found that women spent 19 hours a week, and men spent 11 hours a week for household chores (Eagly and Carli, 2007). In Turkey, in 2014, about 11 million out of 28 million people were not involved in the labor force because they were busy with household chores and unfortunately the whole number is female (TUIK, 2015a).

In addition, the roles of co - mother - housewife imposed on women and internalized by themselves during the socialization process negatively affect women 's entering into working life and developing promotion expectations (Gunindi \& Ersoz, 1998). Women do not see the management as appropriate due to the traditional patterns of sexual identity (Karcioglu \& Leblebici, 2014).

The most prominent organizational barriers are injustice in employment practices. Gender roles, combined with maledominated organizational cultures, lead to gender discrimination in working life (Akdol, 2009). Although there are many laws that prohibit gender-based employment and paying different wages to men and women for the same job, societies still consider women as secondary (Palmer ve Hyman, 1993). As a result of gender discrimination, a woman is more likely to be in a lower position than a man of the same qualification, after several years of work, at the same time she joins the working life (Wirth, 2004).

The small number of women in the management levels makes it difficult to establish a mentoring relationship. Lack of mentor relationship negatively affects women's management careers (Ataay, 1998). In addition, women's inability to enter the communication networks of male colleagues is another disadvantage of women in working life (Soysal, 2010).

Stereotypes and professional discrimination are barriers stemming from social factors. Gender stereotypes form the basis of prejudices that prevent women from coming to management. Generally accepted judgments that good managers are men lead to underrepresentation of women in senior management (Çelikten, 2004). It is thought that women cannot lead as well as men in the organization, that they cannot make reasonable and correct decisions because they act with emotions, that male managers will not want to work with female managers, and that male employees will not want to take 
orders from female managers. Women are regarded as docile, humane and emotional, and men are considered violent and rational. Therefore, it is considered more appropriate for men to be in the decision-making position (Yogun \& Ercen, 2008; Karaca, 2007; Barutcugil, 2008).

On the other hand, professional discrimination is based on judgments such as "women's work" and "men's work" against occupations in the society. In general, "women's work" consists of low status and paid, temporary, insecure and unqualified jobs, while "men's work" consists of high paid, continuous, secure and qualified jobs requiring authority and responsibility (Parlaktuna, 2010). Women are guided to work in professions that do not contradict the characteristics attributed to them from childhood. These professions are generally teachers, secretaries and nursing who are seen as extensions of maternity and housewife duties in the workplace (Bhasin, 2014). Jobs such as engineering, judiciary, law and health administration are also considered "men's jobs" (Wirth, 2004).

Glass ceiling barriers for women also apply to educational organizations. According to global statistics; In 2012, the ratio of female teachers worldwide was $94.1 \%$ in pre-school, $62.5 \%$ in primary school, $54.5 \%$ in lower secondary education, $51.9 \%$ in secondary education and $48.8 \%$ in upper secondary education (UNESCO, 2012). Although the majority of female teachers are in the primary education level, it is seen that their number decreases significantly as they go to upper levels (Wirth, 2004).

According to Tan (1996), administration of education in Turkey is an area which is usually dominated by male values and carried by men (Tan, 1996). In Turkey, 504,042 teachers (55,32\%) out of 911,216 in formal education are women teachers (TUIK, 2015b). On the other hand, 7.7\% of school principals and 19.9\% of the vice principals are women (MEB, 2014). The situation is worse for women in provincial and district administrators. 2 (2.5\%) of 81 Provincial National Education Directors and $5(0.6 \%)$ of 859 District Directors of National Education are women (KSGM, 2014).

These data clearly show that although women are more likely to be employed in educational organizations than men and the teaching profession is seen as a female profession, women do not or cannot come to management positions. In the light of this information, the purpose of this study is to reveal the opinions of educational administrators about the factors that arise from the glass ceiling syndrome which prevents women from becoming senior managers in educational organizations (central and provincial organizations of the Ministry). For the general purpose of the research, the following questions were sought:

1. What are the opinions of the administrators on the individual, organizational and social factors that prevent women from becoming senior managers in educational organizations (central and provincial organizations of the ministry)?

2. What are the suggestions of managers to ensure that women are represented more in higher managerial positions?

\section{Method}

Qualitative method was used in this research. The research was conducted as a descriptive study in the survey model. Qualitative research is defined as a qualitative process which aims to present perceptions and events in a realistic and holistic way in the natural environment by using qualitative data collection methods such as observation, interview and document review (Simsek ve Yildirim, 2011).

\subsection{Participants}

The participants of the study consisted of administrators working in Niğde Provincial and District National Education Directorates and schools affiliated to the center. The maximum variation sampling method was used to determine the participants. The purposeful sampling, in which the most suitable ones for the purpose of the study were taken, has emerged within the qualitative research tradition. In the maximum variation sampling, it is aimed to reflect the variety of individuals who may be party to the problem at the maximum level (Simsek \& Yildirim, 2011). The distribution of participants by position and gender is presented in Table 1 . 
Table 1. The Distribution of Participants

\begin{tabular}{llll}
\hline & Position / Gender & Frequency & Percentage \\
\hline \multirow{4}{*}{ Position } & Provincial Director & 1 & 3.2 \\
& District Director & 5 & 16.1 \\
& Branch Director & 11 & 35.5 \\
& School Principal & 3 & 9.7 \\
& Vice Principal & 11 & 35.5 \\
\multirow{3}{*}{ Gender } & Total & 31 & 100.0 \\
& Male & 18 & 51.1 \\
& Female & 13 & 41.9 \\
& Total & 31 & 100.0
\end{tabular}

The participants of the research were; 31 managers with maximum variety according to the variables of duty, gender, age, seniority of administration, marital status, and having a child. Participants are also vary in terms of age, seniority, marital status and having children.

\subsection{Data Collection}

In the study, semi-structured interview technique was used to examine and reveal the views of the participants in depth. For the interviews, a semi-structured interview form was developed by the researcher. During the development phase, expert opinion was taken and pilot implementation was conducted with two participants. In the interview form, questions were put forward to reveal the opinions and suggestions of the participants regarding individual, organizational and social barriers that prevent women from reaching the senior managerial positions in educational organizations and to ensure that women are represented more in higher managerial positions in educational organizations.

\subsection{Validity and Reliability}

In order to ensure validity and reliability, detailed information about the sample and the process was given. Participants' responses were not interfered with in order to present the participants' views as they were, and they were guided through some additional questions in order not to go beyond the subject and capture the details. The questions were asked to all participants in the same way. While transcribing audio recordings, attention was paid to coding each expression in the correct category, capturing details, and removing unnecessary and repeated information from the report.

In order to ensure the reliability of the analysis of the views, sub-themes of each theme were identified, interview coding key was prepared and coding was done after the interview was made. The opinions of the participants were re-coded to this key by a non-researcher and the consensus was determined.

\subsection{Data Analysis}

Content analysis method was used in the analysis of data obtained through interviews. Content analysis aims to reach relationships and concepts by bringing together similar data within the framework of certain concepts and themes. Content analysis consists of (1) finding themes, (2) coding data, (3) arranging themes, (4) interpreting the findings. If the literature is rich enough to help create categories, the researcher can identify the categories at the beginning of the study (Simsek \& Yildirim, 2011). In this study, the themes were formed at the beginning of the study with deductive approach, in accordance with the theoretical framework and sub-objectives of the research.

In the research, the frequency of expressing opinions was determined and similarities and differences were interpreted. The frequencies of the distribution of participants' views according to themes and sub-themes are given. During the interpretation of the findings, direct quotations from the participants were included in order to be more concrete and explanatory.

\section{Results}

The findings of the research are reported as subtitles according to the themes. These themes are:

1. Individual factors leading to the glass ceiling

2. Organizational factors leading to glass ceiling

3. Social factors leading to glass ceiling

4. Suggestions for overcoming glass ceiling barriers 


\subsection{Participant Opinions on Individual Factors}

The participants of the study were asked the question "What are the individual factors that prevent successful and qualified female teachers from becoming senior managers in educational organizations?". Sub-themes created according to the participant responses and the frequencies of these views are presented in Table 2.

Table 2. Sub-themes for individual factors and frequencies

\begin{tabular}{l|c}
\hline Sub-themes & Frequency \\
\hline Perception of management profession & 30 \\
\hline Multiple role-playing & 25 \\
\hline Spouse's profession & 21 \\
\hline Inability to receive support from spouse or family & 24 \\
\hline Personal characteristics & 23 \\
\hline
\end{tabular}

Participant opinions were analyzed within the scope of these themes.

\subsubsection{Perception of Management Profession}

According to the participants, women generally do not want to take on managerial duties. One of the most important reasons for this is that, compared to teaching, management means a lot more work, yet a lot less leave and vacation. In addition to this, the area of responsibility in the management is expanding and this necessitates dealing with a lot of work and people. For these reasons, women refrain from assuming managerial duties. One participant expressed this opinion with the following words:

"The higher the managerial position, the more the area of responsibility and the number of people responsible. More responsibility means more trouble. Therefore, women do not prefer to progress in management positions." (OYk5).

Reasons other than these basic reasons are that women prefer teaching instead of a passive managerial duty (IYe5); women think that management will negatively affect their relationship with their immediate surroundings (IY6); management is not financially attractive (IYe9).

\subsubsection{Multiple Role-Playing}

Multiple role playing refers to that the woman takes on all or several roles such as mother, spouse, housewife and manager. The participants stated that women had difficulty in performing the roles they played in addition to the role of working women, that they had a role conflict and that they had to give up the managerial role first. They stated that the role of women, especially the role of motherhood, outweighed other roles and that women instinctively gave priority to motherhood. In addition, women being held responsible for domestic and childcare activities alone prevent them from making a career. One participant expressed this view with the following words:

"Housework and childcare are often the sole responsibility of women. Women try to fulfill these responsibilities fully, which makes career development a secondary issue." (IYe2)

There are also opinions stating that prenatal and postnatal leave during women's childbearing process causes women to miss opportunities for promotion in managerial positions.

\subsubsection{Spouse's Profession}

The participants stated that the spouses of women could not be assigned to high level managerial positions due to their professions or they did not have the opportunity to be promoted. The reasons for this are varied. One of the most cited reasons (IYk2, IYe6, IYe7, IYe10, IYe11) is the fact that women are in a higher status or prestige profession than men are not welcome by the society. One participant (IYe10) expressed this opinion with the following words: "Turkish society does not approve that a woman has a better profession or higher status than her husband. This creates social pressure on spouses."

The management career of women who are constantly forced to change cities due to her husband's profession is negatively affected. In Turkey, in some occupations such as judge, district governor, military personnel it is compulsory to change cities at certain intervals. Therefore, women change their cities with their spouses and cannot find a career opportunity in one place. In addition, the fact that the spouse works in a very demanding job makes it difficult for a woman to aspire to a managerial position. 


\subsubsection{Inability to Receive Support From Spouse or Family}

According to the participants, the inability of women to receive support from their spouses or family prevents women from coming to top managerial positions. This support is expressed in different meanings. Spouse support means that for some participants, men help women in housework and childcare. Some interpret this support as psychological support and encouragement.

A participant (OYe4) emphasized that the husband should support the woman in housework with the words: "Lack of support from her husband in housework and childcare can prevent women from escalating to senior managerial positions." Another participant (IYe6) highlighted the need for psychological support and courage for women with the words: "In order for women to rise in managerial positions, their spouses should give them psychological support and encouragement."

Some participants state that spouses do not support women and they deliberately try to prevent them from becoming a manager. The reason for this is to prevent women from passing in front of men as social status.

\subsubsection{Personal Characteristics}

The participants think that some of the personal characteristics of women prevent them from rising to managerial positions. According to the participants, the personal characteristics that prevent women from becoming senior managers are listed in Table 3.

Table 3. Personal characteristics and participants

\begin{tabular}{l|c}
\hline Characteristics & Frequency \\
\hline Lack of self-confidence & 7 \\
\hline Internalizing gender roles & 5 \\
\hline Non-combatants & 5 \\
\hline Not being career oriented & 4 \\
\hline Avoiding risk & 4 \\
\hline Being overly emotional & 2 \\
\hline Avoidance of responsibility & 2 \\
\hline Being an extreme perfectionist & 1 \\
\hline Not being open to criticism & 4 \\
\hline
\end{tabular}

According to the participants, the internalization of gender roles (mother, housewife, etc.) towards women in the society causes women not to aspire to management positions. Some participants stated that women developed a belief that they could not be a manager and this led to lack of self-confidence and non-struggle. The participants expressed this situation as learned helplessness. Some participants see that women are not career-oriented, that they see management as risky and avoid taking risks and responsibility as obstacles to their rise. Some of the participants also think that the perfectionism, non-criticism and excessive emotional characteristics of women which are not suitable for management prevent them from rising to management positions.

\subsection{Participant Opinions on Organizational Factors}

The participants of the study were asked the question "What are the organizational factors that prevent successful and qualified female teachers from becoming senior managers in educational organizations?". Sub-themes created according to the participant responses and the frequencies of these views are presented in Table 4.

Table 4. Sub-themes for individual factors and frequencies

\begin{tabular}{l|c}
\hline Sub-themes & Frequency \\
\hline Organizational culture and policies & 22 \\
\hline Failure to participate in communication networks & 17 \\
\hline Lack of mentor & 8 \\
\hline
\end{tabular}

Participant opinions were analyzed within the scope of these themes. 


\subsubsection{Organizational Culture and Policies}

The culture and policies of educational organizations are one of the organizational barriers to women's managerial careers. The participants talked about male domination in the senior management levels in educational organizations and stated that this domination led to the arrangement of jobs for men. According to the participants, the masculinization of jobs may cause women not to be preferred for these positions. In addition, due to their family responsibilities, general acceptances that women cannot work outside of working hours and cannot go to non-provincial posts cause women not to prefer these positions. Furthermore, according to the participants, women are not appointed as managers because it is difficult for both female and male employees to receive orders from female managers. Moreover, senior executives do not prefer women for managerial positions as they cannot work comfortably with women. The participants expressed their views with the following words:

"The job descriptions of the senior management positions and the division of labor have been adjusted for men due to the long-standing male-dominated organizational structure, and management jobs have become masculine." (IYk1, IYe6, IYe8, IYe13, OYk6, OYk9).

"Male managers do not prefer women because they think they will work more easily with men." (IYe4, OYe2).

"Both female and male employees do not like to take orders from women." (IY6, IY7, OYk1, OYk2, OYk4, OYk9).

"For the benefit of the organization, if necessary, you have to go to the coffeehouse, the mosque, and address everyone. Sometimes at midnight the wall of the village school collapses and the plumbing fails. Management doesn't mean to work only in office and in working hours. A woman may not be able to handle them." (IYe8).

As can be seen, the pre-acceptance and sexist approach towards women lies at the basis of organizational culture and policies that prevent women from becoming senior managers. The male-dominated culture keeps women away from managerial positions with pre-assumptions that women cannot be managers, that managerial work is man's work and that no one would want to work with women managers.

\subsubsection{Failure to Participate in Communication Networks}

According to the participants, the communication networks between the top executives are very important in appointing managerial positions. Women's inability to participate in these networks is an obstacle for women to rise. Participants base this problem on two main reasons. Women cannot participate in or do not prefer to participate in networks between men. Women's family responsibilities have an important effect on this. Two participants expressed their views with the following words:

"It is a serious loss for women to not be able to enter the communication network of men."(IYk1).

"Sometimes we spend time outside of working hours. Women can't come between us, they don't spend time with us. They cannot communicate with us." (IYe4).

According to the participants, the other reason is that women could not establish such a network among themselves because they were jealous of each other and did not want them to rise. According to this view, there is a very serious competition between women and they do not want each other to rise. That is why they cannot establish a supporting network. Two participants expressed their views with the following words:

“Women try to leave each other behind. That's why they can't make many friends. Therefore, communication between women becomes weak."(OYe3).

"Women are jealous of each other and see them as rivals. A woman does not want another woman to rise or even tries to prevent it." (OYk2).

The fact that those who expressed these opinions were both male and female participants makes the finding more interesting.

\subsubsection{Lack of Mentor}

According to the participants, one of the obstacles for women to come to senior management positions is the lack of mentors. Only 8 male participants expressed this view. Participants think that management is not just about legislation or information to be obtained through technology. According to the participants, guiding by the managers who are more experienced and working in higher levels supports the rise of women who have just started to manage. The participants expressed their views with the following words:

"For example, imagine a woman who has just begun to manage. It reads the regulation but needs to learn where it is lacking by exchanging information from experienced top managers." (Iye3).

"Management cannot be learned from the internet. Women need guidance. Guidance supports their ascension." (IYe14). 
“Nobody can raise itself. That's my personal opinion. You need a guide." (Oye4).

Some participants think that the fact that more men are employed in senior managerial positions makes women deprived of guidance. One of the participants (OYe3) said, "Women may experience difficulties because managers are mostly men. It's better if she gets help from her kind."

\subsection{Participant Opinions on Social Factors}

The participants of the study were asked the question "What are the social factors that prevent successful and qualified female teachers from becoming senior managers in educational organizations?". Sub-themes created according to the participant responses and the frequencies of these views are presented in Table 5.

Table 5. Sub-themes for social factors and frequencies

\begin{tabular}{l|c}
\hline Sub-themes & Frequency \\
\hline Professional discrimination & 22 \\
\hline Stereotypes & 16 \\
\hline
\end{tabular}

Participant opinions were analyzed within the scope of these themes.

3.3.1 Professional Discrimination One of the factors that prevent women from coming to senior managerial positions is that management is not seen as a profession suitable for women in society. According to the participants, the perspective of the society affects people's choice of profession. The widespread beliefs and acceptances in the society have led to the separation of occupations into male and female occupations. A manager (IYe7) stated his view as "According to the society, nursing, teaching and secretarial were women's professions; blacksmithing, chauffeering and military service are perceived as male professions". According to the participants, management is accepted among male professions. A manager's (IYk2) statement expresses this situation: "In general, management is seen as man's work.".

According to some participants (IYe6, IYe10), there are two reasons why management is seen as a male job. The first is that women prefer the professions that women work in; the second is that women participate in working life well after men and therefore men take managerial positions before women.

One of the striking findings in this regard is that many participants (IYe2, Iye3, IYe7, IYe13, OYe3, OYe4, OYk9, IYk3, ) expressed that management was more suitable for men and some professions were more appropriate for women. More interestingly, these views were expressed by both male and female participants.

\subsubsection{Stereotypes}

Another obstacle to the glass ceiling for women is the stereotypes formed against women. These stereotypes have a negative impact on decisions to appoint women to senior management positions. According to the participants, it is stated that the stereotypes in Table 6 about women's management are common.

Table 6. Stereotypes about women's management

\begin{tabular}{l|l|c}
\hline \multirow{4}{*}{ Women } & Stereotypes about women & Frequency \\
\hline & cannot be good managers & 7 \\
\cline { 2 - 3 } & are very emotional & 5 \\
\cline { 2 - 3 } & do not take risks & 3 \\
\cline { 2 - 3 } & cannot make the right decisions & 2 \\
\cline { 2 - 3 } & are not hard enough & 1 \\
\cline { 2 - 3 } & are not as dependent on their careers as men & 2 \\
\hline
\end{tabular}

One participant explains the source of these stereotypes:

"Society still has a hard time seeing women as people who work or manage. She can't do her job right, she can't run well. Why is that? Because women are treated as a breed to be married. The woman will only get married, stay at home, do household chores, give birth and care." (IYe5).

One striking aspect of the findings is that male participants mostly adopted and advocated these stereotypes. Two participants (IYe9, IYe13) argue that women are very emotional and involve their emotions in their decisions. Three participants (IYe5, IYe9, IYe13) stated that women avoid harm or take risks because they are afraid of danger. One participant (IYe10) stated that women do not struggle as much as men and do not depend on their careers in order to both rise and maintain their position. These views show that stereotypes in society are adopted by many managers. 


\subsection{Suggestions for Overcoming Glass Ceiling Barriers}

The participants of the study were asked the question "What are your suggestions for overcoming the barriers faced by successful and qualified women in achieving senior managerial positions in educational organizations?". Participant responses were addressed in two main themes: suggestions for women and suggestions for politicians. The frequencies of the sub-themes are presented in Table 7.

Table 7. Sub-themes and frequencies for suggestions for overcoming glass ceiling barriers

\begin{tabular}{l|c}
\hline Sub-themes & Frequency \\
\hline Suggestions for women & 23 \\
\hline Suggestions for politicians & 21 \\
\hline
\end{tabular}

Participant opinions were analyzed within the scope of these themes.

3.4.1 Suggestions for Women The participants of the research think that women employees should make some efforts to overcome glass ceiling barriers and to reach the top managerial positions. In this context, the participants made some suggestions for women. The participants' suggestions for women are summarized in Table 8 .

Table 8. Suggestions for women to overcome glass ceiling barriers

\begin{tabular}{l|l|c}
\hline & Suggestions for women & Frequency \\
\hline \multirow{4}{*}{ Women should } & be willing and aspire to senior management duties & 20 \\
\cline { 2 - 3 } & be combative & 4 \\
\cline { 2 - 3 } & trust themselves & 4 \\
\cline { 2 - 3 } & be brave & 2 \\
\cline { 2 - 3 } & improve themselves & 2 \\
\cline { 2 - 3 } & set a career goal & 1 \\
\hline
\end{tabular}

The participants mostly stated that women should be more willing and persistent in order to be promoted to senior managerial positions. According to the participants, there are no legal obstacles to the rise of women. However, women are not very keen on coming to such positions and do not make enough effort. This is evidenced by the fact that very few women apply for executive appointment exams. Two participants expressed their views on this issue:

"Women must first be demanding. They need to be willing to do the job. Nobody calls you to be a manager. This is rarely seen. You need to indicate that you are willing to do this job, make yourself noticed, take exams and interviews." (IYe6).

"When the exams for vice principal and branch director are opened, most women don't even apply. There is no situation in the legislation that may pose an obstacle to women. The problem is that women don't want to, do not apply to these tasks. They must overcome this obstacle first." (IYe14).

In addition, the participants stated that women need to be more courageous, confident, and try to reach their own career goals in order to overcome the glass ceiling barriers and advance their careers. In order to achieve these goals, it was suggested that women should improve themselves professionally and be more equipped.

\subsubsection{Suggestions for Politicians}

According to the participants, it is not enough for women to make an effort to overcome the glass ceiling barriers. For this, politicians also need to take initiative. In this context, the suggestions of the participants to the politicians are summarized in Table 9. 
Table 9. Suggestions for politicians to overcome glass ceiling barriers

\begin{tabular}{l|c}
\hline Suggestions for politicians & Frequency \\
\hline Quota should be reserved for women in management positions & 12 \\
\hline Women should be paid an additional fee & 9 \\
\hline Flexible working hours should be set for women & 6 \\
\hline Organizations having women managers should provide nursery or kindergarten & 6 \\
\hline Appointment should be based on merit & 2 \\
\hline Female managers should be appointed at young ages & 1 \\
\hline Maternity leave must be extended & 1 \\
\hline
\end{tabular}

Participants mostly focused on positive discrimination against women and quota implementation. Accordingly, the fact that a certain portion of senior executive positions is reserved for women alone will enable women to be represented more in these positions. In addition, the most important suggestions are aimed at meeting the needs of women, such as housework and child care, which prevent women from seeking management. It was stated that women should be supported with additional fees in order to meet their other responsibilities such as childminder and housework. In this way, management positions will become more attractive for women. In addition, it is stated that extending the working hours according to the needs of the women will ensure that women will demand more administrative duties. In addition, opening of nursery schools and kindergartens in the organizations where women managers work will make management more attractive for women. The views of some participants on this issue are expressed as follows:

"If the quota is allocated to women in senior management positions, it will be easier for them to rise. Politicians should make it legal. If there are six vice principals in a school, at least half of them should be female. It's not that hard."(OYk4).

"The teacher is paid as much as I do. Management doesn't have any charm. If the woman has no one to take care of her child at home, extra fee will be paid for childminder. Then management will be more attractive for women. "(IYe10).

"Working hours can be stretched for women. So she can finish her work and go home early, or come an hour early and go an hour late. Managers can organize this among them." (IYe6).

Apart from these suggestions, the participants stated that merit should be taken as a basis in the appointment, that female managers should be appointed at a young age and that the prenatal and postnatal leave should be extended.

\section{Discussion and Conclusion}

Individual factors are one of the most important barriers to the appointment of women to senior management positions. One of these factors is women's multiple roles. Women's multiple roles such as mothers, spouses, housewives and managers prevent them from rising to senior managerial positions. Women who assume more than one of these roles naturally have problems in terms of time. Accordingly, women stay away from management. Women who have children can also give up the goal of taking senior managerial positions because they consider maternity duties as a priority. Findings obtained from similar studies (Orucu, Kilic and Kilic, 2007; Karaca, 2007; Eroglu Toraman, 2011) show that women avoid managerial duties because of their multiple roles. In the study of Eroglu Toraman (2011), 35\% of the female employees stated that they avoided managerial duties because of their family responsibilities. In this regard, Deemer and Fredericks (2003) argue that women make more efforts to balance the career and personal life than men do. Because women are burdened more than men. For centuries, the primary role of women has been towards family and home life. Societies have not yet adapted to the participation of women in business life. For this reason, the responsibilities related to business life are added to the personal responsibilities. Palmer and Hyman (1993) stated that the research on the impact of family life on women's work life is the main finding that spouses and children interrupt a woman's career. According to Earl (2019), most of the women think that they should choose between their children and careers mostly due to the gender roles they internalize. One of the reasons for this is that organizational policies do not support women trying to establish a work-family balance. According to the researcher, flexible organizational structure will support women in overcoming the glass ceiling barrier resulting from the multiple roles they have undertaken. The point of view of management, the profession of the spouse, the lack of support from the spouse and the family, and the personal characteristics are the individual factors of secondary importance after undertaking multiple roles.

Organizational culture and policies are an obstacle for successful and merit women to rise to senior managerial positions. The structure of the male-dominated organization leads to the fact that senior management duties are arranged for men and women cannot come to these positions. Men have assumed managerial duties for years and this has led to the fact that senior management in the organization and society is seen as a male job. This disintegration, which is widely accepted 
in the society, is still accepted by male managers in many organizations and may cause women to be shifted from these positions. This leads to general acceptance of inconvenience of encouraging women to management tasks and employment policies based on gender discrimination. Therefore, it is understood that male managers prefer men when choosing managers because they think that they will work together more easily. According to Palmer and Hyman (1993), the most obvious organizational barriers to achieving power are unfair employment practices. Kumas and Fidan's (2005) study on female employees stated that all of the participating female employees were sexually discriminated on the basis of hiring, wage, job training and especially career progression. Collischon (2019) stated that women sometimes work under adverse conditions than their male colleagues who have the same equipment and do the same job. According to Tan (1996), the two factors that are effective in legitimizing the existing inequalities are that men are accepted as leaders in work and in society and that taking orders from women is not welcome. The JP Morgan Chase study (2018) "The Case for Gender Balance" states that investors focus on boards with female representation as gender diversity increases the diversity among boards. Diversity reduces the risk of group thinking and improves the ability of boards to conduct effective oversight of company management, but the progress is slow.

In addition, it is possible to mention that women are not wanted by their fellow men in managerial positions. As a matter of fact, Kenny (2018) stated in his research that the majority of the participants stated that the humiliating speeches directed at them were mostly made by their fellow men. Similarly, Schwartz (2019) found that female participants think that they are excluded by their fellows. However, the researcher also mentioned that such problems experienced by women with their fellows pushed them to seek a leadership position.

Besides, women's failure to participate in the communication networks among the managers is one of the important obstacles for women. According to Deemer and Fredericks (2003), networking is the basis for progress in career. For this reason, most men are aware that their networks will be useful for their career advancement. Women, on the other hand, often disregard networks. In their study, Deemer and Fredericks (2003) found that almost all of the participating women wanted to rise through the evaluation of their work, not through communication networks. As in communication networks, women have problems in finding mentors in business life. As they are deprived of mentors who guide and help them, it becomes difficult for them to rise in career stages.

Another obstacle for women to be managers is the stereotypes of women in society. There are widely accepted stereotypes for women in society: Women cannot be good managers, cannot take risks, make decisions with emotions and are not dependent on their careers. Similarly, in its report, the US Glass Ceiling Commission (1995) included stereotypes that women could not be good managers, were very emotional and not harsh enough, and stated that women, regardless of ethnicity, were subjected to stereotypes. Due to these stereotypes, it becomes difficult for women to be appointed to senior management positions. Although it can be said that women have social and economic rights and freedoms in the modern society structure, as Guldal (2006) and Akoglan (1997) stated, negative perceptions against women still exist and it is very difficult to change.

Although it is difficult to overcome the glass ceiling barriers for women to assume senior executive positions, some solutions may be proposed. First, the elimination of individual barriers of women should be emphasized. Women need to be more willing, persistent and challenging to come to senior managerial positions. However, women should improve themselves professionally, set career goals and have confidence in themselves. However, in order to make these easier, the factors that cause women not to want managerial positions should be eliminated. These are problems that can be solved by politicians. Politicians should make their managerial positions preferable and more attractive for women through their decisions and legal regulations. In addition, the male-dominated structure in these positions can be changed in favor of women through quota allocation for women in management positions. Facilitating measures should be taken for other responsibilities such as family, children, household chores that prevent women from choosing management. Additional payment for childcare, nursery support in the institution, flexible working hours can be offered in this context. Increasing the number of women in senior management positions with such incentives will make it easier to remove the glass ceiling barriers.

\section{References}

Acker, J. (2009). From glass ceiling to inequality regimes. Sociologie du travail, 51(2), 199-217. https://doi.org/10.4000/sdt.16407

Akdol, B. (2009). Cam Tavan ve Kurumsal Bir Strateji Pozitif Ayrımcıllk; Ilaç Sektöründe Bir Sinıflandırma. [Glass Ceiling and A Corporate Strategy Positive Discrimination; A Classification in the Pharmaceutical Industry] (Unpublished master's thesis). Istanbul: Istanbul University, Social Sciences Institute.

Akoglan, M. (1997). Konaklama Endüstrisinde Kadın Yöneticiler.[Female Executives in the Hospitality Industry] Eskisehir: Anadolu University Publications: 994. 
Ataay, N. A. (1998). Kadın Yöneticilerin Kariyer Boyutları ve Etmenleri. [Career Dimensions and Factors of Women Managers] O. Çitci (Dü.), 20. Yüzyılın Sonunda Kadınlar ve Gelecek Konferansı (19-21 Kasım 1997) (pp. 237-253). Ankara: TODAIE Publications.

Barutcugil, İ. (2008). İş Hayatında Kadın Yönetici. [Female Manager in Business Life] Istanbul: Kariyer Publications.

Bhasin, K. (2014). Toplumsal Cinsiyet "Bize Yüklenen Roller". [Social Gender: "Roles Installed on Us"] (K. Ay, \& Z. Sarıhacıoğlu, Çev.) Istanbul: Kadınlarla Dayanışma Vakfi.

Celikten, M. (2004). Okul Müdürü Koltuğundaki Kadınlar: Kayseri İli Örneği. [Women in the School Principal's Seat: The Case of Kayseri Province]. Journal of Social Sciences Institute, (17), 91-118.

Collischon, M. (2019). Is There a glass ceiling over Germany? German Economic Review, 20(4), 329-359. https://doi.org/10.1111/geer.12168

Deemer, C., \& Fredericks, N. (2003). Cam Tavan Üstünde Dans.[Dance on the Glass Ceiling] (S. Özer, Çev.) Istanbul: Optimist.

Eagly, A., \& Carli, L. L. (2007). Woman and the Labyrinth of Leadership. Harward Business Review. Retrieved from https://hbr.org/2007/09/women-and-the-labyrinth-of-leadership on 01/04/2015.

Earl, J. (2019). The glass ceiling conquered: An exploratory assessment of women in senior positions in the facilities management sector in Ireland. Dublin, National College of Ireland. Unpublished master's thesis.

Erdem Tuzlukaya, Ş., \& Selçuk, F. Ü. (2013). Çalışma Yaşamı ve Kadın. [Working Life and Women] C. Ertung, L. Gultekin, G. Gunes, \& A. Simsek In, Toplumsal Cinsiyet ve Yansimaları [Gender and Its Reflections] (pp. 4-6). Ankara: Atılım University Publications.

Eroglu Toraman, B. (2011). Eğitim Örgütlerinde Kadınların Yönetsel Konuma Yükselmelerinde Cam Tavan Etkisi. [The Effect of Glass Ceiling on the Promotion of Women to Managerial Positions in Educational Organizations]. (Unpublished master's thesis), Gaziosmanpaşa University, Social Sciences Institute. Tokat, Turkey.

Guldal, D. (2006). Kadın Yöneticileri Motive ve Demotive Eden Faktörlerin Tespitine Yönelik Bir Araştırma. [A Research on the Determination of Factors Motivating and Demotivating Women Managers]. (Unpublished master's thesis). Çukurova University, Social Sciences Institute. Adana, Turkey.

Gunindi, E. A. (1998). Kamu Yönetiminde Yönetici Olarak Çalışan Kadınların Geleneksel ve Çalışan Kadın Rollerine İlişkin Beklentileri. [Expectations of Women Working as Administrators in Public Administration Regarding Traditional and Working Women Roles]. O. Çitci (Dü.), 20. Yüzyllın Sonunda Kadınlar ve Gelecek Konferansı. [The Conference on Women and Future at the End of the 20th Century]. (November 19-21, 1997) In (pp. 255-264). Ankara: TODAIE Publications.

Hu, T., \& Yun, M. S. (2008). Is the Glass Ceiling Cracking? A Simple Test. IZA Discussion Paper: 3518, 1-12. Institute for the Study of Labor (IZA), Bonn, Germany.

Hymowitz, C., \& Schellhardt, T. D. (1986). The glass ceiling. The Wall Street Journal. Special Report on the Corporate Woman. March 24, 1986.

KA. DER. (2015). KA.DER Istatistikleri. [KA.DER Statistics] Association for Supporting Women Candidates. https://doi.org/10.4172/2332-0915.1000155

Karaca, A. (2007). Kadın Yöneticilerde Kariyer Engelleri: Cam Tavan Sendromu Üzerine Uygulamalı Bir Araştırma. [Career Barriers in Women Managers: An Applied Research on Glass Ceiling Syndrome]. (Unpublished master's thesis). Selçuk University, Social Sciences Institute. Konya, Turkey.

Karcioglu, F., \& Leblebici, Y. (2014). Kadın Yöneticilerde Kariyer Engelleri: "Cam Tavan Sendromu" Üzerine Bir Uygulama. [Career Barriers in Women Managers: An Applied Research on Glass Ceiling Syndrome]. Ankara University, Journal of Economics and Administrative Sciences, 28(4), 1-20.

Kenny, A. (2018). Women in positions of influence exploring the leadership journeys of Irish women. Dublin, National College of Ireland. Unpublished master's thesis.

KSGM. (2014, Haziran). Türkiye'de Kadın. [Women in Turkey]. Retrieved from http://kadininstatusu.gov.tr/uygulamalar/turkiyede-kadin on 03/02/2015.

Kumas, H., \& Fidan, F. (2005). Akademisyen ve Tekstil İşçileri Karşılaştırması Örneğinde Çalışan Kadınların Çalışma Olgusuna Bakışları.[The views of working women on working phenomenon in the example of comparison of academicians and textile workers]. Journal of Social Politics Conferences, (50), 507-532.

MEB. (2014). T.C. Milli Eğitim Bakanlı̆̆ Strateji Geliştirme Başkanlığı. [Strategy Development Directorate of the 
Ministry of National Education]. Retrieved from http://sgb.meb.gov.tr/www/milli-egitim-istatistikleri-orgun-egitim2013-2014/icerik/95 on 01/03/2015

Mizrahi, R., \& Aracı, H. (2010). Kadın Yöneticiler ve Cam Tavan Sendromu Üzerine Bir Araştırma. [A Research on Women Executives and Glass Ceiling Syndrome]. Organizasyon ve Yönetim Bilimleri Dergisi, III(1), 149-156.

Morgan, J. P. (2018) The Case for Gender Balance, https://www.jpmorgan.com/global/research/esg-gender- balance, [Accessed on: 17 February 2020].

Narin, M., Marsap, A., \& Gurol, M. A. (2006). Global Kadın Girişimciliğinin Maksimizasyonunu Hedefleme: Uluslararası Arenada Örgütlenme ve A ̆g Oluşturma. [Targeting Maximization of Global Women Entrepreneurship: Organizing and Networking in the International Arena]. Gazi University Journal of Economics and Administrative Sciences, 8(1), 65-78.

Orucu, E., Kilic, R., \& Kilic, T. (2007). Cam Tavan Sendromu ve Kadınların Üst Düzey Yönetici Pozisyonuna Yükselmelerindeki Engeller: Balıkesir İli Örneği. [Glass Ceiling Syndrome and Barriers for Women to Rise to the Executive Level: The Case of Balıkesir Province]. Celal Bayar University, Journal of Management and Economics, 14(2), 117-135.

Palmer, M., \& Hyman, B. (1993). Yönetimde Kadınlar [Women in Management] (Woman and Management Developing the Skills that Work) (1. b.). (V. Üner, Çev.) Istanbul: Rota Publications.

Parlaktuna, I. (2010). Türkiye'de Cinsiyete Dayalı Mesleki Ayrımclığın Analizi. [Analysis of the Occupational Discrimination Based on Gender in Turkey]. Ege Academic Review, 10(4), 1217-1230. https://doi.org/10.21121/eab.2010419607

Schwartz, F. N. (2006). Kadınlar: İş Yaşamının Kaçınılmaz Bir Buyruğu. İçinde: İş Yaşamında Kadınlar. [Women: An Inevitable Command of Business Life In: Women in Business Life]. Harvard Business Review (L. Aslan, Çev. pp. 161-185). Istanbul: MESS.

Schwartz, R. (2019). Support from above the glass ceiling: Narratives of women as university student leaders. Charleston, Illinois, Eastern Illinois University. Unpublished master's thesis.

Soysal, A. (2010). Türkiye'de Kadın Girişimciler: Engeller ve Fırsatlar Bağlamında Bir Değerlendirme. [Women Entrepreneurs in Turkey: An Evaluation in the Context of Obstacles and Opportunities]. Ankara University, SBF Journal, 65(1), 83-114. https://doi.org/10.1501/SBFder_0000002153

Tan, M. (1996). Eğitim Yönetiminde Kadın Azınlık.[ Women Minority in Educational Administration]. TODAIE Journal, 29(4), 33-42.

TUIK. (2015a). İsgücüne Dahil Olmayanların Ylllar ve Cinsiyete göre İsgücüne Dahil Olmama Nedenleri. [Reasons of non-labor force for not being included in the workforce by years and gender]. Retrieved from http://www.tuik.gov.tr/PreTablo.do?alt_id=1068 on 04/04/2015

TUIK. (2015b). Örgün Eğitim Istatistikleri.[Formal Education Statistics] Retrieved from: http://www.tuik.gov.tr/PreTablo.do?alt_id=1018 on 15/0/2015.

U.S. Glass Ceiling Commission. (1995). Good for Business: Making Full Use of Nation's Human Capital. Cornell University ILR School. Federal Publications.

UNDP in Turkey. (2014, July 24). Research \& Publications / Explanatory note on the 2014 Human Development Report composite indices. Retrieved from http://www.tr.undp.org/content/dam/turkey/docs/Publications/hdr/2014\%20\%C4\%B0nsani\%20Geli\%C5\%9Fme\% 20Raporu\%20-\%20A\%C3\%A7\%C4\%B1klama\%20Notu\%20\%28T\% C3\%BCrkiye\%29.pdf On 10/03/2015

UNESCO. (2012). Percentage of Female Teachers by Teaching Level of Education. United Nations Educational, Scientific and Cultural Organization. Retrieved from http://data.uis.unesco.org/index.aspx?queryid=178 On 04/04/2015.

Wirth, L. (2004). Breaking through the Glass Ceiling: Woman in Management. Geneva: International Labour Office.

Yildirim, A., \& Simsek, H. (2011). Sosyal Bilimlerde Nitel Arastirma Yontemleri. [Qualitative research methods in the social sciences]. Ankara: Seckin Publishing.

Yogun, E. A. E. (2008). Kadınların Cam Tavanı Aşma Stratejileri: Büyük Ölçekli Türk Işsletmelerinde Bir İnceleme. [Women's Glass Ceiling Crossing Strategies: A Study in Large-Scale Turkish Enterprises]. (Unpublished doctoral dissertation), Çukurova University, Social Sciences Institute. Adana, Turkey.

Notes 
This manuscript was produced from the master's thesis of Dr. Burcu Akkaya under the advising of Prof. Dr. Yasemin Karaman Kepenekci at the Institute of Educational Sciences in Ankara University, Ankara, Turkey.

\section{Copyrights}

Copyright for this article is retained by the author(s), with first publication rights granted to the journal.

This is an open-access article distributed under the terms and conditions of the Creative Commons Attribution license which permits unrestricted use, distribution, and reproduction in any medium, provided the original work is properly cited. 